\title{
Evaluation of Community Behavior in New Normal Facing the Covid 19 Pandemic in Bandung Raya Civil Servants
}

\author{
Budi Setiawan* \\ Public Sector Business Administration \\ Polytechnic of STIA LAN Bandung \\ Bandung, Indonesia \\ *buchesetiawan@yahoo.com
}

\author{
Iwan Kurniawan, Raisa Rafifiti C., Hendrikus T.G. \\ Development State Administration \\ Polytechnic of STIA LAN Bandung \\ Bandung, Indonesia
}

\begin{abstract}
Changes in people's behaviour is one of the keys to success towards a new normal life that is safe from the transmission of the corona virus that causes COVID-19. The government has taken mitigation and handling steps as optimally as possible so that the virus does not spread and brings more victims. This study aims to determine people's behaviour in the new normal after several mitigation steps are carried out in the new normal era. This research method used a descriptive qualitative approach with purposive sampling in the civil servants in Bandung Raya. The results showed that most people's behaviour still applies health protocols in the new normal era such as wearing masks, using disinfectants / hand sanitizers / soap to wash their hands, avoiding handshakes and crowds, and maintaining distance in the work environment. Based on these results, it can be concluded that the community, especially in civil servants in Bandung Raya, has adapted by implementing health protocols in the new normal era to prevent the spread of Covid19.
\end{abstract}

Keywords—behavior, public servants, covid 19

\section{INTRODUCTION}

Since the end of December 2019 until May 2020 the world has been hit by an outbreak of COVID-19 or coronavirus [1]. Positive cases of the Corona virus in Indonesia have reached 5,923 today [2]. That number increased by 407 people compared to the previous day. "The positive confirmation is 5,923 people," said the spokesman for the government regarding the handling of the Corona Virus Outbreak, Achmad Yurianto, in a press conference broadcast on YouTube BNPB, Friday (17/4/2020). The description of the development condition of the Covid-19 case in Indonesia that the author has done for temporary observation will be described based on the Secondary Data at that time sourced from the Covid-19 Task Force in Indonesia are as follows (figure 1):

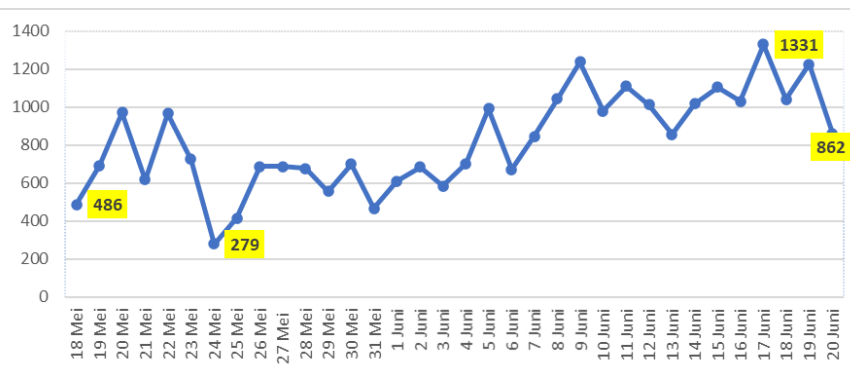

Fig. 1. Development of Covid-19 exposure cases from 18 May - 20 June 2020 in Indonesia (BNPB June 2020).

While the conditions for people who died because of Covid-19 are as follows (figure 2):

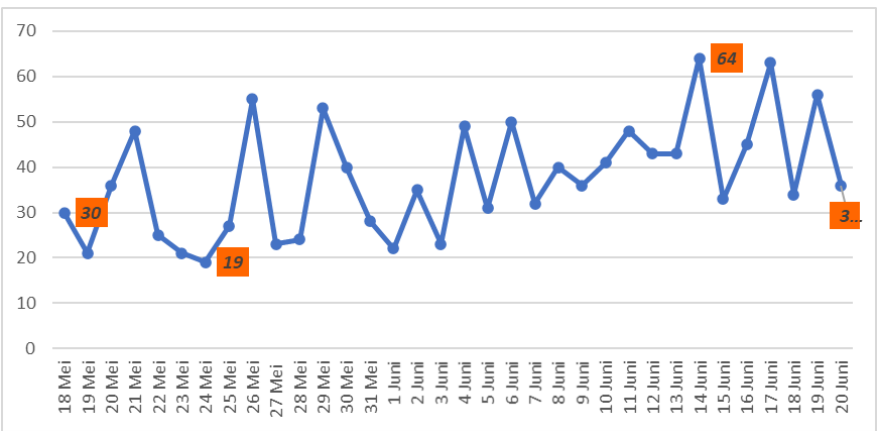

Fig. 2. Development of Covid-19 death cases from 18 May - 20 June 2020 in Indonesia (BNPB June 2020).

The government quickly in July for several regions / regions have started to implement a new civilization pattern (New Normal) with the hope that there will be an improvement in the economic side of the community or hope that there will be new awareness of the community in facing the Covid-19 pandemic. As for seeing the current condition of Confirmed Patients, Died, Healed and Under Treatment, it can be detected from the exposure graph as follows (figure 3): 


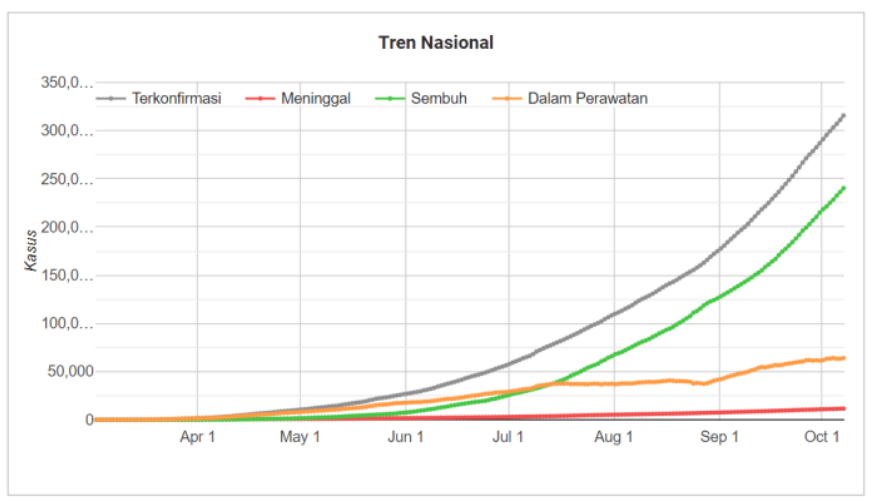

Fig. 3. Development of confirmed cases, died, healed and under treatment for Covid-19 cases nationwide (Kompas 2020).

For the comparison conditions for the addition of confirmed patient cases, patients who died and patients who managed to recover for the last few days are as follows (figure 4):

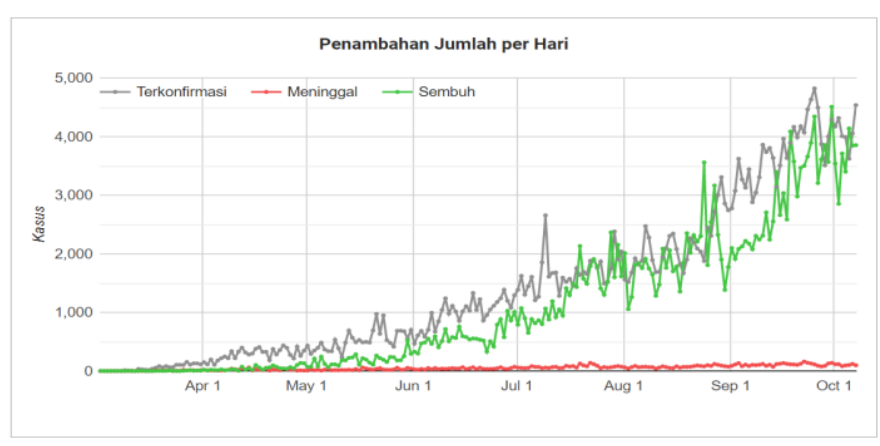

Fig. 4. Comparison of the addition of confirmed cases, deaths and recovers in development per day of Covid-19 cases nationwide (Kompas 2020).

Based on the conditions of this problem, the authors are interested in trying to do a study of people's behaviour in carrying out the new civilization pattern before the new normal and after the new normal is applied. In this way, it is hoped that we can study some of the behavioural models that exist in society in responding to the Covid-19 pandemic in the Greater Bandung area, especially for employees who work in office environments. The objectives to be achieved in this research are as follows:

- To identify people's behaviour before a new civilization was rolled out compared to after the introduction of a new civilization in the Greater Bandung area.

- To understand the level of public awareness in responding to the Covid-19 pandemic in the Greater Bandung area.

- To find out the level of discipline and patience of the Indonesian people, especially in the Greater Bandung area in dealing with the Covid-19 case?
- To anticipate the development of the spread of the Covid-19 virus by paying attention to people's behaviour after implementing the New Normal lifestyle.

\section{MethodS}

\section{A. Approach Research}

In this case the research method used is descriptive research method. Descriptive research as stated by Sukmadinata [3] is A form of research aimed at describing existing phenomena, both natural phenomena and man-made phenomena. This phenomenon can be in the form of forms, activities, characteristics, changes, relationships, similarities, and differences between one phenomenon and another. After the application of a new civilization pattern in the face of the Covid-19 Pandemic in the Greater Bandung area.

To strengthen this descriptive research method, the authors tend to use an approach based on quantitative and qualitative data. This is motivated because research with a quantitative approach is basically research that comes from changes in data based on the movement of historical data which will be analysed further, to predict conditions that will occur in the future. Quantitative research is a process of finding knowledge using data in the form of numbers as a tool to analyse information about what you want to know [4]. The characteristics of quantitative research are as follows [4-7]:

- Using deductive thinking patterns (rational - empirical or top-down), which seeks to understand a phenomenon by using general concepts to explain specific phenomena.

- The logic used is positivistic logic and avoids subjective things.

- The research process follows a planned procedure.

- The purpose of quantitative research is to compile nomothetic science, namely the science that seeks to make laws from generalizations.

- The subjects studied, the data collected, and the data sources needed, as well as the data collection tools used were in accordance with what had been previously planned.

- Data collection is done through measurements using objective and standard tools.

- Involves calculating numbers or quantifying data.

- The researcher places himself separately from the object of research, in the sense that he is not emotionally involved with the research subject.

- Data analysis was carried out after all data was collected.

- In data analysis, researchers are required to understand statistical techniques. 
- The research results are in the form of generalizations and predictions, regardless of the context of time and situation.

- Quantitative research is also called scientific research.

\section{B. Data Collection Techniques and Data Analysis}

More complete exposure for each data collection and analysis technique can be selected one or a combination of several data collection techniques and data processing techniques, as well as assessment, this is done through:

- Document Review, namely extracting data and information from various existing documents that have been released in the Covid-19 Task Force and Secondary Data which are sourced from reliable data.

- Distribute questionnaires to respondents using positive sampling to employees via the existing questionnaire link via the Google form.

- Observation, namely the collection of data / information regarding the implementation of an activity or a series of activities within a certain period.

Meanwhile, in terms of data analysis techniques are used as efficiently as possible in relation to various research methods as previously discussed. Various data analysis techniques include using descriptive analysis methods / techniques with cross tabulation and trend analysis through the frequency of respondents' answers. Furthermore, from the two stages of this analysis technique, it is continued to the stages of preparing policy recommendations related to the behaviour of the existing community and the use of existing data to contribute to the field of study related to the development of the Covid-19 Pandemic in the Greater Bandung area and its surroundings.

\section{RESULTS AND DISCUSSION}

\section{A. Characteristic of Respondent}

The number of respondents taken as the sample of this study is 100 respondents consisting of 52 women (52\%) and 48 men (48\%). Respondents' age was grouped into 5 groups, namely less than 21 years, 21 to 30 years old, 31 to 40 years old, 41 to 50 years old, and over 50 years old. The age group of less than 21 years and 21 to 30 years old consisted of 21 people, the 31 to 40 years age group consisted of 27 people, the 41 to 50 age group consisted of 13 people, and the age group over 50 years there were 18 people. Most of the respondents have S2 / S3 education, as many as 50 people and 66 people who are married and work in government agencies, as many as 45 people. For more details and details, Table 1 explains the characteristics of the respondents, namely as follows.
TABLE I $\quad$ PROFILE OF RESPONDENTS

\begin{tabular}{|c|c|}
\hline Characteristic & Total \\
\hline \multicolumn{2}{|l|}{ Gender } \\
\hline Male & 48 \\
\hline Female & 52 \\
\hline \multicolumn{2}{|l|}{ Age Group } \\
\hline$<21$ & 21 \\
\hline $21-30$ & 21 \\
\hline $31-40$ & 27 \\
\hline $41-50$ & 13 \\
\hline$>50$ & 18 \\
\hline \multicolumn{2}{|l|}{ Last education } \\
\hline High school & 35 \\
\hline Diploma (D1-D3) & 4 \\
\hline S1 & 11 \\
\hline S2/S3/Postgraduate & 50 \\
\hline \multicolumn{2}{|l|}{ Marital status } \\
\hline Single & 32 \\
\hline Married & 66 \\
\hline Divorced & 1 \\
\hline Death divorced & 1 \\
\hline \multicolumn{2}{|l|}{ Profession } \\
\hline Student & 19 \\
\hline Unemployed & 2 \\
\hline Governmant / Civil servant & 45 \\
\hline Private & 8 \\
\hline Housewife & 2 \\
\hline Public services (education, health, social etc) & 19 \\
\hline Transportation & 3 \\
\hline Bank & 1 \\
\hline Agriculture, animal husbandry, forestry and fisheries & 1 \\
\hline
\end{tabular}

In terms of age characteristics, respondents have the youngest age, namely 18 years, while the oldest is 66 years old. By looking at the respondent's field of work, the respondents were divided into several job classifications but during this pandemic there were 71 respondents who were still working, 3 people were working but were being sent home, and 26 people did not work.

\section{B. Internal and External Environmental Conditions}

Your own habits are very important to be maintained and nurtured both physically and psychologically to avoid Covid19. In addition, the development of people affected by Covid 19 is increasing day by day. Various environments, including homes, workplaces, and so on, do not escape demanding new habits in the form of implementing health protocols. The following is a picture of the personal development habits of several respondents during the past week (figure 5). 


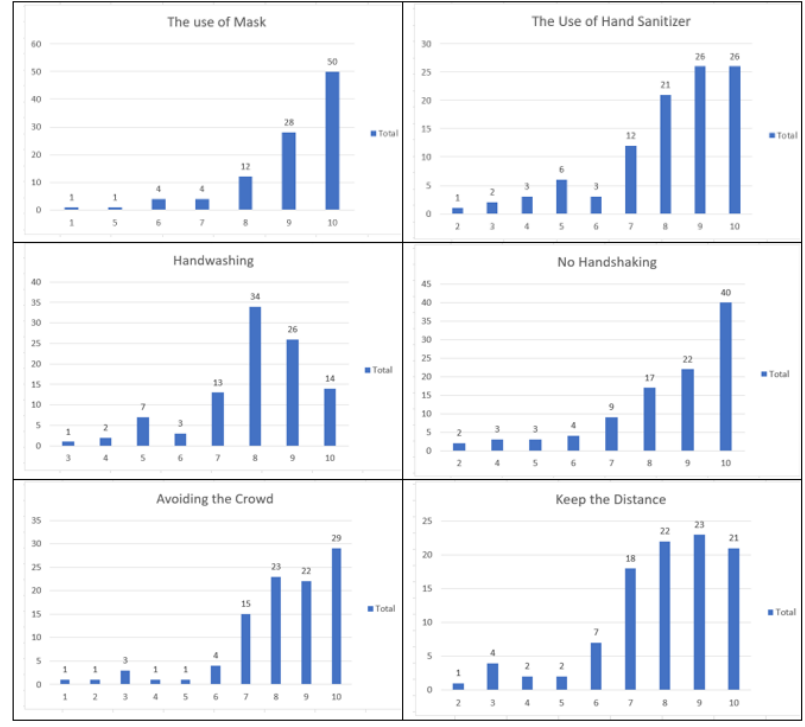

Fig. 5. Habits of several respondents during the past week.

Based on the six pictures above, the community, especially in the civil service environment, still feels effective in preventing the spread of Covid-19. Activities that support health protocols must be carried out wherever and whenever regarding public activities. The spread of the Covid 19 virus is very massive. So far, no cure for this virus has been found. The government has collaborated with several companies that produce vaccines, but they still need time to manufacture and test their feasibility. During the waiting process, further effective prevention efforts by implementing health protocols to reduce the spread of Covid 19.

In addition to the government with the Covid 19 task force (Satgas Covid 19) conducting education about prevention efforts, not a few people reject the implementation of this health protocol. With various reasons for refusing to apply health protocols, most of the people reason that doing work becomes difficult when implementing health protocols, there are no sanctions, and the price of PPE (masks, hand sanitizers, etc.) tends to be expensive. For more details, see Figure 6 shows several reasons why people do not apply health protocols, namely as follows (figure 6).

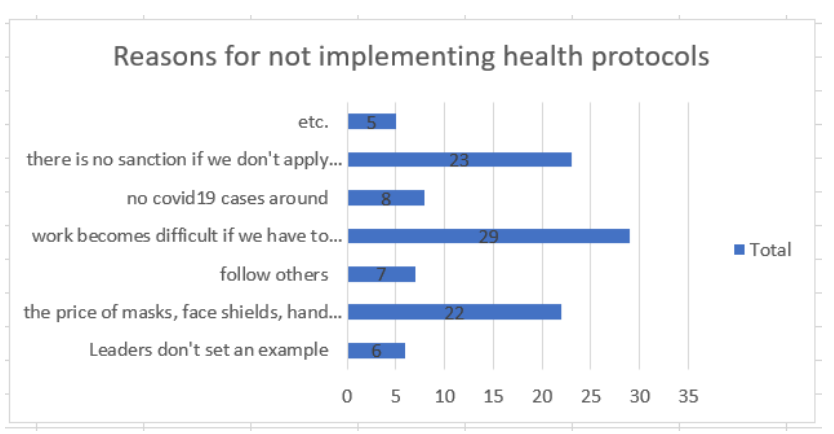

Fig. 6. Description of the reasons for people not implementing health protocols.
The community environment is required to implement health protocols by the government even though there are still those who violate it for various reasons. All elements of society should be able to evaluate the incident regarding Covid 19, namely the outbreak experienced by the whole world. Therefore, people must unite with each other to fight this Covid. If someone is exposed to Covid, the response given to those affected by Covid must apply strict protocols and provide support and do not isolate them. This Covid can happen to anyone, including officials, civilians, the military, and all walks of life. The public's response to Covid-19 sufferers is as follows.

\section{Comparison Before and After PSBB}

In March - July 2020 the government issued a PSBB (Large-Scale Social Restrictions) policy. This restriction applies to all Indonesian people. Based on Figure 7. The frequency of leaving the house has been less since the PSBB was implemented.

\section{Comparison of frequency of leaving the house.}

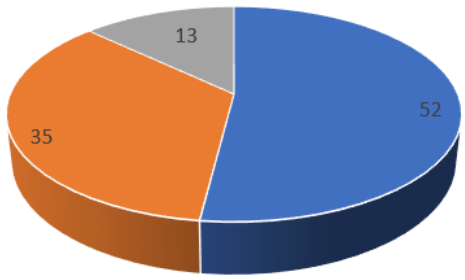

- Less " Equal " More

Fig. 7. Comparison of frequency of leaving the house.

\section{Use of Public Facilities}

Places that need to be considered in the public include workplaces, malls / plazas / shopping centres, markets and street vendors, and public service places. Most people have implemented health protocols in public places (figure 8). From each of the five public places, workplaces that have implemented health protocols. In addition, malls/plazas/shopping centres, places of worship, public service places have implemented 3M (washing hands, wearing masks, and maintaining distance). Markets and street vendors are places that are not visited by most of the respondents. 


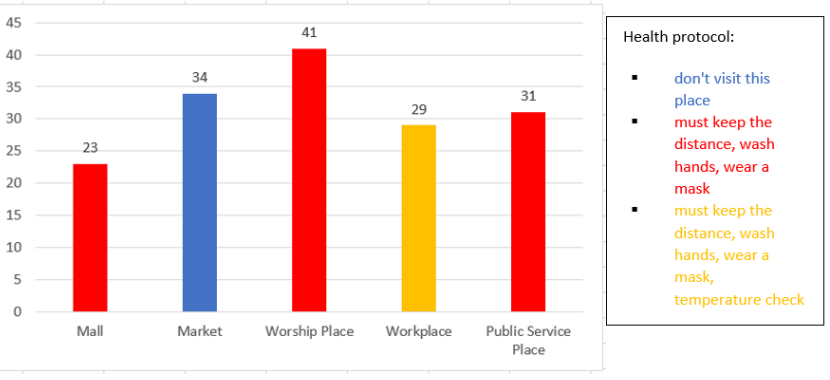

Fig. 8. Public place.

Public transportation also influences the spread of Covid19. Most of the people are users of public transportation. To want a target passenger, the driver who oversees the passenger often ignores him. However, during this pandemic, respondents are increasingly aware that public transportation is a bit difficult to control regarding passenger quotas. Therefore, people reduce the use of public transportation as shown below (figure 9).

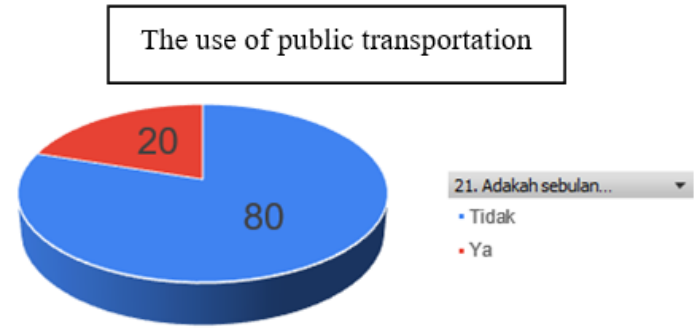

Fig. 9. Use of public transportation.

\section{E. Chances of Getting Covid 19}

Looking at the graph of developments affected by Covid 19 , the number of people affected by Covid 19 continues to grow. It is undeniable that the implementation of protocols in the community and people's habits that cannot be hindered due to economic needs have become one of the dilemma factors for handling Covid 19. From the perception of respondents, most of them think that it is possible for the community to be exposed to Covid 19 even though they have tried to implement health protocols (figure 10).

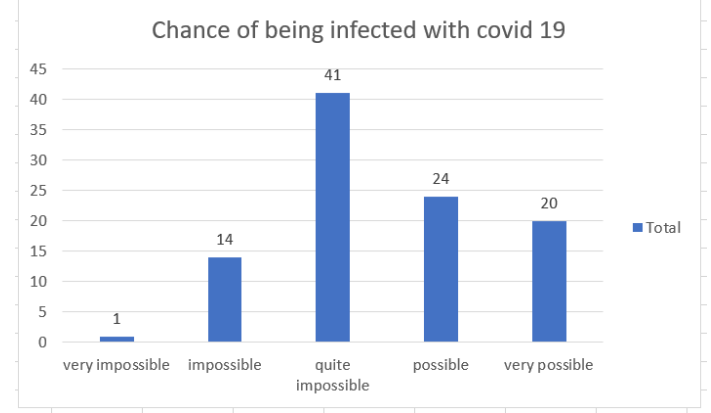

Fig. 10. Respondents perception of chances of getting Covid 19.
The implementation of health protocols is closely related to the government's incessant socialization to the public. In the following, we can see in Figure 11, the information media that disseminates a lot about health protocols including online media, social media, television, and WhatsApp. The most influential media in disseminating the application of health protocols is social media such as FB, Twitter, YouTube, Tiktok, and so on as shown in Figure 11. This indicates a significant shift to television in the delivery of information along with the rapid development of technology. Now television is not the main thing in the delivery of information. Social media has played an important role in socializing the enforcement of health protocols. Not a few big companies do marketing on social media because they see the tendency of people to use internet facilities more often on gadgets/smartphones.

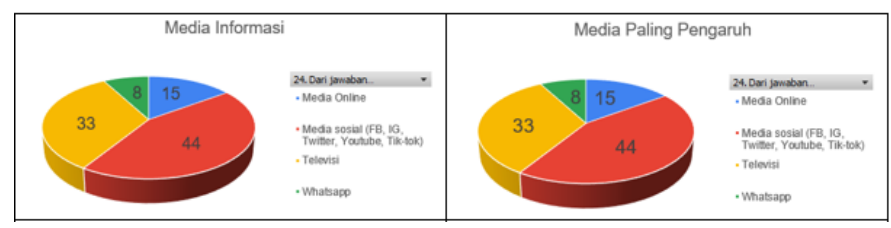

Fig. 11. Information media figure and most influential media.

\section{CONCLUSION}

Based on several findings from the research results in the form of Evaluation of Community Behaviour in New Normal Life Orders in Civil Servants, it can be concluded as follows:

- Most respondents consisted of women, aged 31- 40 years, postgraduate graduates, married, and working in the government / civil servant / defence environment.

- Most of the environmental conditions internally and externally in the community have implemented health protocols. However, besides all that, there are still some who have not implemented health protocols due to difficulties in working, the price of PPE tends to be expensive, and there are no strict sanctions for violating health protocols.

- Comparison before the PSBB (March-July), most of the community was reduced to leaving the house.

- The use of public facilities such as workplaces and religious services, markets, malls, and so on are used by the community daily, most people apply health protocols. Not only that the use of public transportation has decreased during this pandemic to reduce the risk of contracting Covid 19.

- Most of the public views it is possible to contract Covid 19 because the trend is still increasing, because of people who are not wholeheartedly aware of implementing health protocols.

- The most effective socialization of the application of health protocols is through social media. 


\section{ACKNOWLEDGMENTS}

This paper and the research behind it would not have been possible without the exceptional support of my institution, Polytechnic of STIA LAN Bandung. For your attention and support in material and non-material terms, you can complete a paper to be published in the Atlantis Press proceedings.

\section{REFERENCES}

[1] Bbc.com, Covid-19: Virus corona diduga sudah menyebar sebelum pertama kali dilaporkan di China pada Desember 2019 [Online] Retrieved from: https://www.bbc.com/indonesia/dunia-55197612, 2020.
[2] F.M. Sidik, Bertambah 407, Kasus Positif Corona di Indonesia Jadi 5.923 Per 17 April 2020 [Online]. Retreived from: DetikNews. https://news.detik.com/berita/d-4980909/bertambah-407-kasus-positifcorona-di-indonesia-jadi-5923-per-17-april-2020, 2020.

[3] S. Sukmadinata, Metode Penelitian Kualitatif. Graha Aksara, 2006.

[4] K. Kasiram, Metodologi Penelitian. UIN-Malang Pers, 2008.

[5] N. Sudjana, Penelitian dan Penilaian Pendidikan. Sinar Baru Algesindo, 2001

[6] R.B. Johnson and L. Christensen, Educational research: Quantitative and qualitative [Online]. Retrieved from: www.south.edu/coe/bset/johnson, 2005 .

[7] S. Arikunto, Prosedur Penelitian: Suatu Pendekatan Praktik. Rineka Cipta, 2002. 